\title{
Antioxidant Activity of Some Selected East Borneo Plants
}

\author{
Islamudin Ahmad ${ }^{1}$, Riski Sulistiarini ${ }^{2}$, Laode Rijai ${ }^{1}$ \\ ${ }^{1}$ Department of Natural Product Pharmacy, Pharmacy Faculty of Mulawarman University, Indonesia \\ ${ }^{2}$ Department of Pharmacology, Pharmacy Faculty of Mulawarman University, Indonesia
}

\begin{tabular}{l}
\hline \hline Article Info \\
\hline Article history: \\
Received Jan 02, 2015 \\
Revised Feb 02, 2015 \\
Accepted Feb 22, 2015 \\
\hline
\end{tabular}

\section{Keyword:}

Antioxidant activity

DPPH

East Borneo

Extract

$\mathrm{LC}_{50}$

\begin{abstract}
The native plants of East Borneo the Costus specious (Koening) J.E. Smith stem, Lagerstroemaspesiosa Pers leaf, Cerberamangans L leaf, Vitistrifolia L fruit., Scurrulaatropurpurea (Blume) Danser root, Bruceajavanica (L.) Merr. leaf, Lygodiummicrophyllum, Bidens Chinensis Willd., Sonneratiacaseolaris L. peel, Sonneratiacaseolaris L. stem is almost underexplored for their potensial benefits. They were extracted by the solvents of increasing polarity (n-hexane, ethyl acetate, and n-butanol) were tested for their free radical activity against DPPH (2.2-diphenyl-1-picrylhydrazyl). The ethyl acetate extract of Costusspesiosus (Koening) J. E. Smith antioxidant were screnned concentration of $68 \mathrm{ppm}$, similarly athyl acetate extract of Vitistrivolia L., showed antioxidant activity at $64.30 \mathrm{ppm}$. As the ethyl acetate extract of Scurrullaatropurpurea (Blume), Bruceajavanica (L.) Merr, Lygodiummicrophyllum and Sonneratiacaseolaris L. stem, showed antioxidant activity at $273.52 \mathrm{ppm}, 91.12 \mathrm{ppm}, 17.39 \mathrm{ppm}$ and $7.03 \mathrm{ppm}$. Nbutanol extract of Lagerstroemaspesiosa Pers, Cerberamangans L, BidenschinensisWilld, and Sonneratiacaseolaris L. peel showed 8.37 ppm, $128.59 \mathrm{ppm}, 18.17 \mathrm{ppm}$ and $54.29 \mathrm{ppm}$ antioxidant activity using DPPH model systems. Owing to the property, the studies can be further extended to exploit them for their possible application for preservation of food products as well as their use as health supplements.
\end{abstract}

\section{Corresponding Author:}

Laode Rijai,

Department of Natural Product Pharmacy,

Pharmacy Faculty of Mulawarman University,

Campus of Pharmacy Faculty of Mulawarman University, Samarinda, East Kaltim, Indonesia, 75119.

Email: laode@farmasi.unmul.ac.id ; islamudinahmad@farmasi.unmul.ac.id

\section{Copyright (C) 2015 Institute of Advanced Engineering and Science. \\ All rights reserved.}

All rights reserved. 
who grow up in East Borneo region that is one sources of antioxidant compounds that has not been a lot of disclosed [1].

A free radical can be defined any molecular species capable of independent existence that contains an unpaired electron in an atomic orbital. The presence of an unpaired electron results in certain common properties that are shared by most radicals. Many radicals are unstable and highly reactive [2]. These free radicals have very short half-life, high reactivity, and damaging activity towards macromolecules like proteins DNA and lipids. Oxidative stress is among the major causative factor in the induction of many chronic and degenerative diseases including atherosclerosis, ischemic heart disease, ageing, diabetes mellitus, imunosupressant, cancer and others. [3]

The purpose this research is conduct screening antioxidant activity in selected East Borneo wild plants with DPPH (2.2-diphenyl-1-picrylhidrazyl) method.

\section{RESEARCH METHOD}

\subsection{Collecting Sample}

Sample was collected and chosen based on folklore or traditional treatment from the society around east Kalimantan. It was determined in dendrology laboratorium of forestry faculty mulawarmanuniversity. It was determined to ensure plant species.It was sorted to dry out and to be extracted.

\subsection{Extraction}

Each sample was extracted using maceration method with different polarity solvent (n-hexane, ethyl acetate and n-butanol). Sample was macerated using n-hexane for 24 hours approximately. Extraction was continued with ethyl acetate and n-butanolin order respectively. Maceration with each solvent was repeated three times.

\subsection{Antioxidant activity Determination}

As much as $1.0 \mathrm{~mL}$ DPPH $0.4 \mathrm{mM}$ put to Volumetrik flask, added a certain number of test material is then added up volume of $5.0 \mathrm{~mL}$ ethanol, mixed for 1 minute, until mixture is homogenous and silenced for 30 minutes. This solution is then measured its absorbance at a wavelength of $517 \mathrm{~nm}$ maximum wavelength which is in preliminary trials. Do negative control absorbance readings anyway i.e. without addition of solution.

The scavenging ability of the plant extract was determined by the following equation : [4]

$$
(\%)=\frac{(\text { Abs.Control-Abs.sample })}{\text { Abs.Control }} X 100 \%
$$

The DPPH radical absorbs at $517 \mathrm{~nm}$ and in a second substrate-free system, antioxidant activity can be determined by monitoring the decrease in this absorbance. Results were reported as the EC50, that is, the amount of antioxidant necessary to decrease by 50\% the initial DPPH concentration [5].

\section{RESULTS AND ANALYSIS}

Dried sample from some different plants such as: Costus specious (Koening) J.E. Smith stem, Lagerstroemaspesiosa Pers leaf, Cerberamangans L leaf, Vitistrifolia L fruit., Scurrulaatropurpurea (Blume) Danser root, Bruceajavanica (L.) Merr.leaf, Lygodiummicrophyllum, Bidens Chinensis Willd., Sonneratiacaseolaris L. peel, SonneratiacaseolarisL.steem. Each sample was extracted using maceration method with different polarity solvent (n-hexane, ethyl acetate and n-butanol). Sample was macerated using n-hexane for 24 hours approximately. Extraction was continued with ethyl acetate and n-butanol in order respectively. Maceration with each solvent was repeated three times.

Antioxidant activity was defined as ability of each extract to inactivating DPPH radical. Parameter for antioxidant activity is called $\mathrm{IC}_{50}$. Sample was mixed with DPPH solution. Absorbance of dpph and sample mixture measured using UV-Vis spectrofotometre at 510-520 nm wavelength. Measurement result showed that maximum wavelength is at $517 \mathrm{~nm}$.

DPPH free radical used in antioxidant activity measurement generally. Purple colour of DPPH solution was resulted from nitrogen's free electron. DPPH radical's free electron reacted with electron from antioxidant compound in sample. Reaction resulted 2.2-diphenyl-1-picrylhydrazyn which changed solution's colour from purple to pale yellow (Figure 1) [6]. 


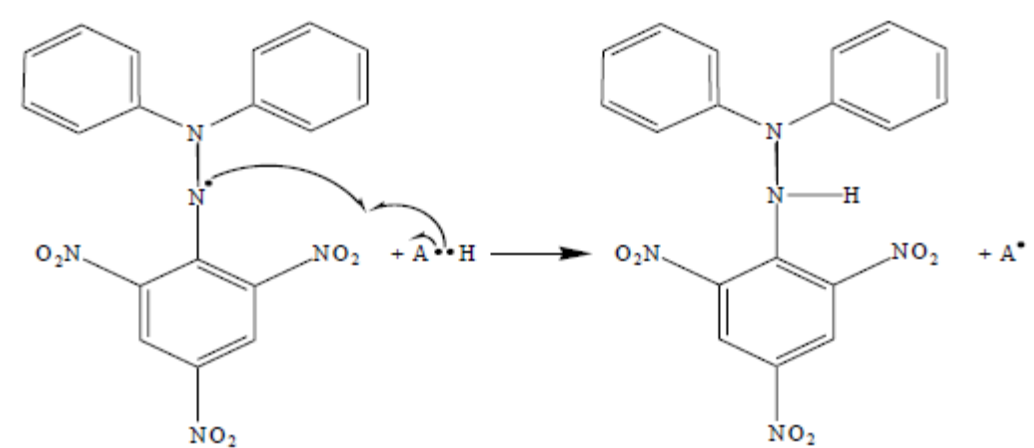

Figure 1. Reaction of Free Radical and DPPH

Table 1. Antioxidant activity of plant extracts

\begin{tabular}{|c|c|c|c|c|c|}
\hline No. & Plants & Ekstract & Equation & $\mathbf{r}$ & IC50 (ppm) \\
\hline \multirow[t]{3}{*}{1} & Costus specious (Koening) J.E. Smith stem & N-heksane & $y=0.2569 x+13.028$ & 0.960 & 143 \\
\hline & & Ethyl Asetate & $y=0.3483 x+26.073$ & 0.951 & 68 \\
\hline & & n-Butanol & $y=0.0679 x+12.358$ & 0.972 & 547 \\
\hline \multirow[t]{3}{*}{2} & LagerstroemaspesiosaPers leaf & n-heksane & $y=1.173 x+28.055$ & 0.983 & 18.7 \\
\hline & & Ethyl Asetate & $y=1.763 x+11.505$ & 0.994 & 21.8 \\
\hline & & n-Butanol & $y=2.761 x+26.877$ & 0.981 & 8.37 \\
\hline \multirow[t]{3}{*}{3} & CerberamangansL leaf & n-heksane & $y=0.0724 x+14.078$ & 0.996 & 496.16 \\
\hline & & Ethyl Asetate & $y=0.1661 x+28.068$ & 0.950 & 132.04 \\
\hline & & n-Butanol & $y=0.2545 x+17.274$ & 0.998 & 128.59 \\
\hline \multirow[t]{3}{*}{4} & VitistrifoliaL fruit & n-heksane & $y=0.201 x+14.590$ & 0.996 & 176.17 \\
\hline & & Ethyl Asetate & $y=0.400 x+24.286$ & 0.987 & 64.28 \\
\hline & & n-Butanol & $y=0.116 x+21.970$ & 0.987 & 241.64 \\
\hline \multirow[t]{3}{*}{5} & Scurrulaatropurpurea(Blume) Danser root & n-heksane & $y=0.138 x+7.173$ & 0.951 & 310.34 \\
\hline & & Ethyl Asetate & $y=0.149 x+9.246$ & 0.897 & 273.53 \\
\hline & & n-Butanol & $y=0.109 x+1.689$ & 0.995 & 443.22 \\
\hline \multirow[t]{3}{*}{6} & Bruceajavanica(L.) Merr. leaf & n-heksane & $y=0.1264 x+21.297$ & 0.972 & 227 \\
\hline & & Ethyl Asetate & $y=0.257 x+26.585$ & 0.937 & 91.12 \\
\hline & & n-Butanol & $y=0.1495 x+26.896$ & 0.960 & 154.54 \\
\hline \multirow[t]{3}{*}{7} & Lygodiummicrophyllum & n-heksane & $y=0.2305 x+4.987$ & 0.992 & 195.28 \\
\hline & & Ethyl Asetate & $y=2.9982 x-2.137$ & 0.996 & 17.39 \\
\hline & & n-Butanol & $y=1.8474 x+4.36$ & 0.974 & 24.70 \\
\hline \multirow[t]{3}{*}{8} & BidensChinensisWilld & n-heksane & $y=0.194 x+2.740$ & 0.997 & 243.61 \\
\hline & & Ethyl Asetate & $y=0.648 x+14.434$ & 0.998 & 54.89 \\
\hline & & n-Butanol & $y=2.596 x+2.826$ & 0.999 & 18.17 \\
\hline \multirow[t]{3}{*}{9} & SonneratiacaseolarisL. peel & n-heksane & $y=0.2737 x+31.3$ & 0.989 & 67.48 \\
\hline & & Ethyl Asetate & $y=0.470 x+1.346$ & 0.992 & 109.24 \\
\hline & & n-Butanol & $y=0.790 x+7.104$ & 0.980 & 54.29 \\
\hline \multirow[t]{3}{*}{10} & SonneratiacaseolarisL.steem & n-heksane & $y=1.601 x+1.370$ & 0.973 & 30.37 \\
\hline & & Ethyl Asetate & $y=5.995 x+7.882$ & 0.991 & 7.03 \\
\hline & & n-Butanol & $\mathrm{y}=4.373 \mathrm{x}+7.604$ & 0.998 & 9.69 \\
\hline
\end{tabular}

Concentration of sample that could scavenge $50 \%$ free radical (IC50) was used to determine antioxidant capacity of sample compared to standard. Sample that had IC50 $<50 \mathrm{ppm}$, it was very strong antioxidant, 50-100 ppm strong antioxidant, 101-150 ppm medium antioxidant, while weak antioxidant with IC50 > 150 ppm[7].

Research resultsin Table 1 indicate that the extract has a very strong antioxidant activity among others Lagerstroemaspesiosa Pressleaves with $\mathrm{IC}_{50}$ values of each extractn-butanol 8.37ppm, 18.7ppmnhexane andethylacetateextract of 21.8ppm. Lygodiummicrophyllumat 17.39ppm ethyl acetate extract and 24.70ppm of n-butanol in $\mathrm{IC}_{50}$. Bidens Chinensis Willd n-butanol extract with $\mathrm{IC}_{50}$ value of 18.17ppm. And Sonneratiacaseolaris L. steem with $\mathrm{IC}_{50}$ values in $7.03 \mathrm{ppm}$ the ethyl acetate and $9.69 \mathrm{ppm}$ n-butanol, and nhexane of $30.37 \mathrm{ppm}$ extract.

The extract of ethyl acetate Costusspecious (Koening) JE Smithstem and Vitistrifolia Lfruit, Bidens Chinensis Willd with respective $\mathrm{IC}_{50}$ of 68ppm, 64.28ppm and 54.89ppm has powerful antioxidant. While extracts which have atioksidan activity being that n-hexane extract of Costusspecious(Koening) JE Smithstem with $\mathrm{IC}_{50}$ of $143 \mathrm{ppm}$, Cerberamangans $L$ leaves with $\mathrm{IC}_{50}$ values in theethyl acetate extract of $132.04 \mathrm{ppm}$ 
and 128.59ppm n-butanol and ethylacetate extracts Sonneratiacaseolaris L.peel with $\mathrm{IC}_{50}$ of $109.24 \mathrm{ppm}$. And extracts which have a weak antioxidant activity of n-hexane extracts Vitistrifolia Lfruit and Lygodiummicrophyllum with $\mathrm{IC}_{50}$ values of each $176.17 \mathrm{ppm}$ and 195.28ppm, and n-butanol extract Bruceajavanica (L.) Merr. Leaves with $\mathrm{IC}_{50}$ of $154.54 \mathrm{ppm}$. While the extract with $\mathrm{IC}_{50}$ values above 200ppm excluding categories that have antioxidant activity.

The antioxidant activity exhibited by plant extracts obtained from the activity is suspected of secondary metabolites present in the plant above [8].

Secondary metabolites are produced or synthesized compounds on cells and certain taxonomic groups in the rate of growth or a particular stress. Secondary metabolites are used as modern medicine among other alkaloids from plants Rouwolvia serpentine, atropine from Hyoscymus niger plant , Caffeine from Coffea Arabica plant, Cocaine from Erythorxyln coca plant, and Vinblastine from Catharanthus roseus [9].

Some secondary metobolit such as phenolic and flavonoid group has recorded a reduction of free radicals activity [9],[10].

In general it can be seen that the best antioxidant activity of each plant in Table 2.

Table 2. The best activity of each plant

\begin{tabular}{clcc}
\hline No & \multicolumn{1}{c}{ Plants } & Ekstract & IC $_{\mathbf{5 0}}$ (ppm) \\
\hline $\mathbf{1}$ & Costus specious (Koening) J.E. Smith stem & EtilAsetat & 68 \\
$\mathbf{2}$ & LagerstroemaspesiosaPers leaf & n-heksan & 18.7 \\
$\mathbf{3}$ & CerberamangansL leaf & n-butanol & 128.59 \\
$\mathbf{4}$ & VitistrifoliaL fruit & EtilAsetat & 64.28 \\
$\mathbf{5}$ & Scurrulaatropurpurea(Blume) Danser root & EtilAsetat & 273.53 \\
$\mathbf{6}$ & Bruceajavanica(L.) Merr. leaf & EtilAsetat & 91.12 \\
$\mathbf{7}$ & Lygodiummicrophyllum & EtilAsetat & 17.39 \\
$\mathbf{8}$ & BidensChinensisWilld & n-butanol & 18.17 \\
$\mathbf{9}$ & SonneratiacaseolarisL. peel & n-butanol & 54.29 \\
$\mathbf{1 0}$ & SonneratiacaseolarisL.steem & EtilAsetat & 7.03 \\
\hline
\end{tabular}

Based on the results of the determination of antioxidant activity (IC50) of some herbsare extracted using solvents with different polarity level (n-hexane, ethylacetate, andn-butanol). Showed that the plants that grow naturally in East Kalimantan region has a very promising potential as a source of natural antioxidants that can be developed into a good health product in dosage form drugs and health sulplemen.

\section{CONCLUSION}

Based on the research that has been done, it can be concluded that results of screening antioxidant activity of various extracts from each plant is known that most of the material has potential as a natural antioxidant from the category of the most powerful to the weak category.

\section{ACKNOWLEDGEMENTS}

Our thanks to all lecturers and all researchers in Pharmacy Faculty of MulawarmanUniversity.

\section{REFERENCES}

[1] Rijai, L.,“Kajian Strategi Pemanfaatan Potensi Tumbuhan Obat Unggulan secara Berkelanjutan”,Desertasi, Sekolah Pascasarjana Institit Pertanian Bogor, 2010.

[2] V. Lobo, A. Patil, A. Phatak, N. Chandra, "Free Radicals, Antioxidants And Functional Foods: Impact On Human Health”,Pharmacogn rev.,vol/issue: 4(8), pp. 118-126, 2010. Doi: 10.4103/0973-7847.70902.

[3] Effat S., "Screening of Thirteen Medicinal Plant Extracts for Antioxidant Activity", Iranian Journal of Pharmaceutical Research,vol/issue: 7(2), pp. 149-154, 2008.

[4] Naima S., MR.Khan, Maria S., "Antioxidant Activity, Total Phenolic and Total Flavanoid Contents of whole Plant Extract Torilis leptophylla L.”, BMC Complementary and Alternative Medicine,vol.12, pp.221, 2012. doi:10.1186/1472-6882-12-221 The electronic version of this article is the complete one and can be found online at: http://www.biomedcentral.com/1472-6882/12/221.

[5] Michael A., Paul DP., Emilios P., Suzanne M., Kevin R., "Methods for testing antioxidant activity”, Analyst, vol. 127, pp. 183-198, 2001. DOI: 10.1039/B009171P.

[6] Molyneux P.,"The Use of the Stable Free Radical Diphenyl Picrylhidrazyl (DPPH) for Estimating Antioxidant Activity”,Sonklanakarin J.Sci. Technol., pp. 211-219, 2004. 
[7] Fidrianny, Irda, Ira R., Komar RW.,“Antioxidant Capacities From Various Leaves Extracts Of Four Varieties Mangoes Using Dpph, Abts Assays And Correlation With Total Phenolic, Flavonoid, Carotenoid”,International Journal of Pharmacy and Pharmaceutical Sciences, vol/issue: 5(4), 2013. ISSN- 0975-1491.

[8] Mariska I.,“Metabolit Sekunder: Jalur Pembentukan dan Kegunaannya”, Balai Besar Litbang Bioteknologi \& Sumber Daya Genetika Pertanian, Bogor, 2013.

[9] Gahafar MS., et. al.,"Flavonoid, Hespiridine, Total Phenolic Contents And Antioxidant Activities From Citrus Species”, African Journals Online,vol/issue: 9(3), 2010.

[10] Amarowicz R., et. al.,"Free Radical-Scavenging Capacity, Antioxidant Activity, And Phenolic Composition Of Green Lentil (Lens cuculinaris)”,Food chemistry,vol/issue: 121(3), pp. 705 - 711,2010.

\section{BIOGRAPHIES OF AUTHORS}

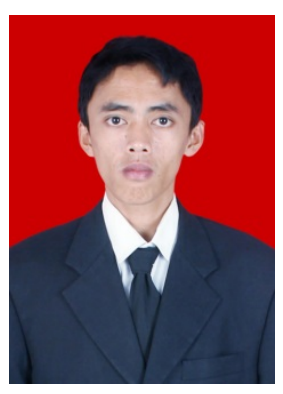

Islamudin Ahmad, S.Si., M,Si., Apt

islamudinahmad@farmasi.unmul.ac.id

$+6281342205060$

Departement of Natural Product Pharmacy, Pharmacy Faculty of Mulawarman University

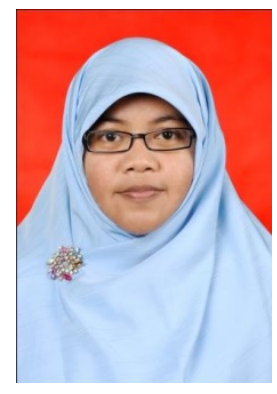

RiskiSulistiarini, S.Farm., M.Si

riski@farmasi.unmul.ac.id

+62 85247257700

Departement of Pharmacology, Pharmacy Faculty of Mulawarman University

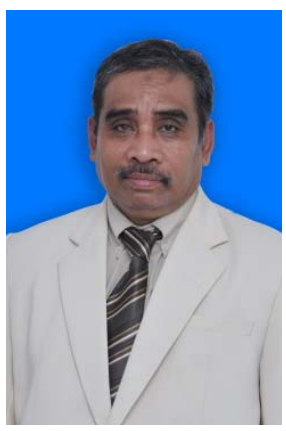

DR. LaodeRijai, M.Si., Drs loade@farmasi.unmul.ac.id +62 85247263809

Departement of Natural Product Pharmacy, Pharmacy Faculty of Mulawarman University 